Oct.

executed on his last letter a rude drawing of a pen and a sword, with the words, "Ten to one the feather beats the iron'! (2) that two hundred years after the event the secret shall be known that Cromwell's body was taken up and buried under an ash tree in Naseby field, and that 'a hot cavalier's head ' was placed where Cromwell's should have been; (8) that it should be known only to the Squire family that Cromwell marched into Peterhorough cathedral, bundling out canons \&c. and preaching in armour; (4) that Squire's ancestor went over to Holland, and met a mysterious men (supposed to be the stadtholder) on the quay, and thet the minntest detail of how the man took snuff 'with an air' before 'elegant ladies' would be handed down viva voce for two hundred years; (5) that Cromwell and Squire had 'pipes and ale' together at Oundle; (6) that Cromwell had a French valet; (7) that royalist treason-letters ware found in the pocket of a pugilistic miller; (8) that Henry Cromwell's amourette provoked the Protector to rage and say, 'Man, man, I could find in my heart to shoot thee down for snch a feat,' but that such rage was checked (how likely!) by an intimation that Squire too carried pistols ; $(\theta)$ that -but surely one need not go into detail about the thirty pieces of silver - the medal-the Barbary corsairs-the silver plunder atill hid in Whittlesea Mere. Why, the whole story is mere midsummer madness ! How, when, where, and by whom could such loose gossip have been preserved?

So far I had written and was about to send my papers to the printers, when it was reserved for the Rev. J. R. Lunn (who had already expressed an adverse opinion as to the genuineness of the brass inscriptions) to finally prick the bladder, by discovering that the French inscription purporting to be to 'Thomas Squire de Squierre,' is nothing more nor less than a verbatim transcript-dates and all-of the brass to Sir Thomas Braunstone, constable of the castle of Wisbech, who died on 27 May 1401 (the very day ascribed to the imaginary Thomas Squire). An engraving of this brass is to be found at p. 67 of Lyson's 'Magna Britannia' (Camb.), a copy of which was added to the Norwich Library in June 1828, and consequently accessible to William Squire. I really hope this will satisfy the champions of the Squire papers, for if it does not I do not think anything will.

WaLter Rye.

\title{
THE HANOVEB PAPEBS.
}

TeE Hanover papers form part of the Stowe collection recently purchased from Lord Ashburnham by the trustees of the British Museam. They consist of a mass of correspondence ranging from 1695 to 1719, and are kept in rough leather covers, but are not yet completely catalogued. Occasionally the letters are copies of originals existing elsewhere; but very few have been printed, except those chosen by Macpherson in 1775 for his collection of 'Original Papers,' dealing with the intrigues at St. Germains and Bar-le-Duc for the purpose of restoring the elder branch of the Stnarts. Macpherson it is true either transcribed or translated the most valuable of the Hanover papers, but enough remain unprinted to 
justify the present attempt to show their historic importance. In the second volume of his ' History of Great Britain from the Restoration to the Accession of the House of Hanover,' Macpherson also refers frequently to the Hanover papers, and this work, too, will be found useful as a guide throngh this maze of hidden information.

Volume i. of the Hanover papers is entitled 'Princes,' and containe holograph letters of William III, Lonis XIV, Marlborough, the electos (George I), the princess Sophis, and many famous characters who fre. quented the court of Queen Anne.

Volume ii. (' Strafford ') contains Lord Strafford's private correspondence with the electress Sophia, and includes communications from the following persons: The earl of Halifax, never a waverer from the protestant cause; the duke of Ormond, apperently ready to make his peace with the elector; Harley, earl of Oxford ; Mr. Francis Harcourt; Mr. Secretary Bromley; the earl of Rochester, leader of the tories; Bir Thomas Henmer; the earl of Stamford; Dr. Hugh Chamberlen; the earl of Peterborough; Tenison, archbishop of Canterbary ; Lord Polwarth; the duke of Buckingham, very much in favour with the Pretender; Sir William Dawes, the eloquent archbishop of York; and Lord Anglesey, with a foot in each camp, Jacobite and Hanoverian.

Volume iii. ('Stair') contains Lord Stair's correspondence from France with the elector's secretary Robethon, the abbé du Bois, Baron Bernstorff, and others, during the yeare 1715-1719. Lord Stair was so accomplished a diplomatist that he was mainly instrumental in foiling the pro-Jacobite schemes in France. He gained over an English Roman catholic priest named Strickland, who was one of the Pretender's cheplains. Hence he knew every project as it was devised, and was enabled to bring pressure on the regent Orleans when most required. The abbe du Bois was the minister who acted for France, and gave ordera at Stair's request for the Pretender's retirement to Avignon in 1717. Lord Stair was equally happy in foiling the Spanish schemes of Cardinal Alberoni, probably the only diplomatic equal he encountered.

Volumes iv. v. and vi. ('Miscellaneons') deal with the years 16921718. The writer has not yet been able to work completely through these.

Volume vii. is headed 'Schätz,' and gives that minister's account of his dealings with the whigs in England during 1718-1714, when be con: solidated the measures taken to supplant the tories who held office at the end of Queen Anne's reign.

Volume viii. ('Bothmar '), 1712-1714. The duke of Marlborough figares largely here. There are also letters of interest from Mr. George Ridpath and M. Schrader.

Volume ix. ('Bothmar [2] ') contains letters received in London after the accession of George I, 1716-1717.

Volume x. ('Rebelles') contains letters and translations of letters into French from Jacobites and their sympathisers during 1717-1719. It is noticesble that Prince Eugene addressed James Edward at a critical moment of his career. Most of these letters were opened in the post abroad, and then found their way to Hanover. It seems, however, that the agents of Princess Sophis, and afterwards those of the elector, 
were but ill informed of what was going on first at St. Germains and then at Bar-le-Duc, where the Pretender lived under the duke of Lorraine's protection, at the time of Queen Anne's death.

Volumes xi. and xii. contain both holograph and copied letters, some of which are to be met with elsewhere (for instance, one or two letters of Lord Bolingbroke, which are included in the Bolingbroke correspondence), bat there are several copies as yet unprinted. It is stated in Mr. Astle's notes that some of these were transcribed from Lord Hardwicke's papers.

The following notice of George I's secretary Robethon, in whose cabinet these documents were found, was probably compiled by Dr. O'Connor, once librarian at Stowe :

' $M$. Robethon was of a French refugee family. He became private secretary to King William III and was employed by the duke of Zell in the same capacity. He was then appointed confidential secretary to the electoral prince of Hanover, afterwards George I. This private intercourse gave him considerable ascendancy over his master; and being a man of address, great knowledge of mankind, and well acquainted with the leading members in both houses of parliament in England, he was enabled to act a conspicuous part. His situation with the king rendered him presumptuous and insolent. His necessities were great and his venality notorious, both Townsend and Walpole reprobating it. Consequently he became their inveterate enemy, jealously promoting the views of Sunderland. He was the most intriguing person of all the Hanoverian junto, which also comprised Count Berensdorff, Baron Bothmar, Baron Schultz, and the Hanoverian ladies.'

The secretary's son, Colonel Robethon, was a very dissipated character, and his effects were sold under an execution in 1752, when a $\mathrm{Mr}$. Duane bought these volumes. He left them with his library to his relation, Mr. Michael Bray of Wimbledon, after whose decease they were purchesed by Mr. Thomas Astle, ${ }^{1}$ who was keeper of the records in the Tower, a trustee of the British Museum, and a well-known writer on antiquarian subjects in the Gentleman's Magazine. His manazcript library at Battersea Rise exceeded that of any private gentleman in England ; and when he died at the age of sixty-eight, in 1809, his manuscripts and Anglo-Saxon charters were purchased, subject to certain conditions, by the marquess of Buckingham and deposited at Stowe, where a room was fitted up in the Gothic style for their reception.

After this sketch of the contents of the Hanover papers and of the history of the collection, we turn to the persons with whom they are concerned.

When Count Bernstorff, the mimister whom George I consulted in his affairs, arrived in England, he was anxions to increase his consequence and improve his fortane. He intrigued against the English ministry, and was afterwards disgraced by the influence of Townshend. ${ }^{2}$ Lord

1 The original letters and papers, in the second volume, relative to the earl of Clarendon's negotiations at the court of Hanover, in 1714, were parchased by Mr. Thomas Astle at the sale of the earl of Clarendon's papers by Baker and Leigh.

2Dr. O'Connor's account in the Hanover papers. Compare Core, Life of Walpole, vol. i. p. 89 . 
Clarendon in a letter from Hanover, written in August 1714, says Bernstorff was governed by Robethon, whom the British envoy 'thought as bed as bed conld be' (Hanover papers).

Bothmar was the principal agent in England from the court of Henover during the latter yeara of Queen Anne, and led the counsels of the Hanoverian junto. It was mainly owing to him that Lord Townshend Was entrusted with the ohief power, and became head of the whig administration after 1714. Bothmar was discontented and considered his services to Townshend ill requited. Of Townshend himself no letters seem to have reached Robethon.

Baron Schütz, the Hanoverian minister in London, was active in all the intrigues of the whigs, and was very adverse to the queen's last ministry. He was forbidden the court on his application for the writ for bringing the electoral prince into England. He afterwards was a member of the German junto, who gave the English ministry much trouble. ${ }^{1}$

The earliest date in the Henover papers belongs to the year 1695 . Six holograph letters from Louis XIV to Marshal Boufflers concerning the defence of Namur appear in this collection. They are dated 6 and $9 \mathrm{July}, 2,8,6$, and 10 Aug. 1695 . It will be remembered that in the summer of 1695 William III at the head of his allies threatened Namur. Louis writes from the Trianon, Versailles, showing an interest in the minutest details of the campaign, such as exploits of officers not of the highest rank. He hed doubtless received intelligence concerning the local topography from Boufflers himself. But besides this he gTasps the military situation in its entirety, and promises to send relief to the threatened city by creating a diversion elsewhere. He writes, 9 July: Jay ordonne an Marchal de Villeroy de faire une diversion considerable en Flandres pour empecher le prince d'Orange de se fortifier d'avantage. Louis also promises that Brussels shall be bombarded by Villeroy. The consequent destruction of 1,500 houses and many public buildings with attendant bloodshed and misery is well known, but until now we had only Villeroy's word for the fact that Louis ordered. the bombardment. ${ }^{2}$ Lrouis' statement to Boufflers runs as follows: Et vous pouvez compter sur le bombardement de Bruxelles. Lord Macaulay probably never saw these Hanover papers, or he would have quoted the French king's letter. Indeed except where Macpherson, writing in 1775, has extracted the letters of obvious value, the mass of the correspondence ander consideration bas never been utilised. Irord Stenhope, for instance, alludes frequently to Macpherson's ' Original Papers ' but not to the Hanover papers themselves.

We may ask ourselves how letters like these ever came into the possession of the authorities at Hanover. When, after marching from Brussels to Namur, es if to relieve the latter place, Villeroy thought better of the matter, and left Bonfflers to a now inevitable surrender, William III arrested the French commander, to his great astonishment, a. a hostage, ${ }^{3}$ and this because the enemy had failed to carry out an

1 O'Connor, ubi supra.

2 Macauley, vol, iv. p. 590 ; Rapin, vol. xiv. p. 235 ; Smollett, vol. i. p. 295.

- Macaulay, vol. iv. p. 597. 
exchange of prisoners at the lately captured cities of Dirmayde and Deynse. Boufflers, not, as be conceived, responsible for the conduct of his compatriots, waxed wroth at being conveyed prisoner to Maestricht. Now as the forces of several German princes, Hanover amongst them, were present at Namur, it wes probably then that Bouffers' correspondence fell into their hands, although it is of course possible that they passed one by one into hostile custody.

Most of the seventeenth century letters - and they are far from numerous-are written to $M$. Robethon. Among his correspondents we find names sach as Pensionary Heinsius, Marshal Tallard, resting at the Hague after negotiating the Spanish partition treaty of 1698 , and Lord Portland, William III's representative at the negotiations. As we enter the eighteenth century, the allusions to affairs in England become more frequent. After the death of the young duke of Gloucester, $24 \mathrm{July} 1700$, and the recognition of the electress Sophia as heir to the English crown, Robethon's cabinet becomes a reritable focus of gossip and intrigue. From the first, the Hanoverian egents teach their court not to put trust in any tory connsels, and we find M. d'Alonne, the ambassador of the princess Sophia at the Hague, telling Robethon that ' the tory party in England simulate affection for the electress.' M. d'Alonne has a compatriot in London who observes events for the electoral family, and noting the fact of a powerful party acting in the Pretender's interest, aays on 7 Nov. 1702: "Wee are not much in paine for any attack that may be intended by some persons on the Bill of Succession, nor against the Bill for Toleration of Dissenters.'

After the accession of Queen Anne, and when war had broken out, several of Robethon's correspondents were anxious for the termination of Cbarles XII's contest with Augustus of Poland. It seems to have been thought that neither the genius of Marlborough-then just asserting itself-nor the determination of the emperor Joseph would effectually check Louis XIV so long as a bitter contest for pre-eminence in northern Europe threatened to detach a portion of the Germanic states from their alliance against France; and indeed neither Prussia nor Holland could observe such a struggle unmoved. For as Bentinck, writing from Hanover, where he was British representative, said in March 1709, 'There exists absolute necessity of re-establishing peace between the kings of Sweden and Poland.' As is well known, these hopes were doomed to disappointment.

Queen Anne was herself prepared to make sacrifices in order to keep the czar in good temper, as wo may learn from an incident described in the Hanover papers. It appears that in 1706 the Russian ambassador, M. Mateof, ${ }^{1}$ had been seized for a debt in London, and the ozar had taken up his case warmly, so that the British government after two years' cor-

1 Miss Strickland (Lives of the Queens of England, vol. xii. pp. 192, 193) and Mr. Hill Barton omit any mention of the procesaion at Mosoom, which is described in Lord Whitworth's manuscript letters, now in the British Museum. It is almost word for word the same as the present account. Owing to Peter the Great's action, the legal position of ambassadors was defined in 1708, and their persons have been since held sacred. Mateof, or son of Matthew, is the name as written in Lord Whitworth's letters. 
respondence despatched a special embassy to Moscow, with Charles, Lord Whitworth, at its head, for the purpose of expressing regret at the occurrence. Lord Whitworth, in a letter to Robethon, gives the following account of the ceremonial observed on this occession:

'The Ambassador's chariot was of gilt lined with green, the footcloth of the same richly layed and embroidered and drawn by six pyed horses.

' Secondly, a handsome chariot painted red, and lined with gilt drawn by six black horses, and the harness trimmed with silver plates.

' Thirdly a chariot very richly gilt lined with red velvet trimmed with silver lace, drawn with six black horses, their harness of very fine gilt, also twelve footmen in red liverys with broad gold galoons interwoven with green and white silk.

- Fourthly four pages on horseback, their coats of fine scarlet richly laid with gold and silver, their sleeves of green brocsde with gold and silver flowers.

'The Czar's coach of state where the Ambassador sat with the master of the ceremonies, his gentlemen of the horse riding by. The March past took near an hour and a half, and the streets [were] thronged with spectators. At his Excellency's coming to the Castle the guard received him with drums beating, colours flying, the officers at the head with their swords drawn, and saluted with their hats.

- The Czar received the Ambassador standing and expressed satisfaction that her Majesty had ordered reparation to be made.

-That his Majesty might very well [have] expected those people who had violated the law of nations in the person of his Ambassador shonld have been punished according to his desires, yet since that could not be by the defect of our former constitutions, his Majesty considering the concern the nation had shewn in the Act of Parliament and the honour her Majesty the Queen had done him by this embassy was willing to accept the satisfaction.'

It is worthy of notice that all the English merchants resident in Moscow were present at this ceremony.

Most of the earlier letters from Englend are formal acknowledgments of the Hanoverian dynasty as representative of the protestant cause, and are chiefly interesting for the names of those who thas professed their fidelity to it. It is certainly remarkable to find many well-known Jacobites amongat them-Sir Thomas Hanmer, Mr. Secretary Bromley, the duke of Buckingham, and above all Lord Ormond. But in Queen Anne's time we know that most public men endeavoured to make themselves safe both at Hanover and St. Germains. The American colonies are, of course, full of loyalty to the electress, whose portrait Mr. John Chamberlayne, gentlemar usher to Prince George of Denmark, presented to the city of Boston. Mr. Joseph Dudley, the governor, wrote accepting the gift, which, he says, shall be placed in the public library.

In the volume marked 'Stair,' which contains several letters of support from Edinburgh, there is but one opinion expressed: 'the nation [i.e. Scotland] was for the Pretender. Our affairs may improve,' says Lord Stair, 'but at present we are sore distressed.' This view 'of the case was constantly expressed ; for instance, by Lord Polwarth, father of Bolingbroke's friend, Lord Marchmont. The Hanover papers add new 
testimony to the importance of the act of union in repressing Jacobite feeling in Scotland.

There is a copied letter amongst the Hanover papers from Lord Bolingbroke to his friend Mr. Drummond, the banker at Amsterdam, relating to the dismissal from court of the dake of Marlborough, which deserves to be recorded :

Lord Bolingbroke to Mr. Drummond, resident of Amsterdam.

'Whitehall : Jan. 28, 1710.

... As to the great man you mention I have wrote a few but plain words to your Pensionary. He was not received with the acclamations you heard of, and they are much mistaken that imagine that he can be upon any other bottom than that what the Queen pleased to pat him.

'I daresay he is convinced by this time that he cannot lead either his mistress or any one else as he used to do. We shall send him over a subject; take care you do not put royalty into his head agsin.

'Adieu. I am ever with the attmost sincerity,

' Your most obedient servant,

'HenRy S. John.'

Mr. John Chamberlayne, Prince George of Denmark's major-domo, gives a list of supporters of the protestant cause. 'Several of my friends and patrons, such as the archbishop of Canterbury, the earl of Halifax, the bishops of Salisbury, Lichfield, Lincoln, and Norwich, Chief Justice Parker, \&c., of whom and many more it would be tedious to enumerate, never bowed the knee to Beal, or never will.'

Among the advocates of the Hanoverian succession in parliament was Jack Howe, member for Gloncestershire, who, although an adept in scurrilous language, had little to recommend him but parliamentary influence.' His letters in the Hanover collection evince a determined fidelity to the electress. Other correspondents with the seme avowed purpose are Peterborough, Galway, and Wharton.

One of the most enthusiastic correspondents in the Hanover collection is Harley, afterwards earl of Oxford, who vies with Queen Anne's maternal uncle Lord Rochester, leader of the tory party, in expressing devotion to her cause. Writing in English, becanse he ssys ' he knows the electress has an English heart,' Harley rolls out sentence after sentence of commonplace such as helps one to understand how he was by no means powerful as a speaker. Harley's letters are mostly contained in Macpherson's collection.

With reference to the question of Harley's intrigues with the court of St. Germains the Hanover papers confirm the view that, irritated by the hostility of foreign agents like Schütz and Bothmar, both Anne and her ministry meditated a change in the succession, to be effected by parliamentary means if the Pretender would change his religion. It is probable, however, that no such position was taken up in England definitely, and that even after Oxford's dismigsal much would have depended on the success of Lord Clarendon's mission to Hanover, details concerning which are given towards the close of this article.

I Stanhope, Roign of Queen Anre, pp. 15 and 62. 
The ministers are said to have asked him to dissemble his faith, bat this would never have contented the queen, who, whatever else may be said of her, never veered in her staunch fidelity to the reformed church of England. Nevertheless her brother wrote with equal decision on the catholic side: "They must not take it ill if I use the same liberty I allow to others to adhere to the religion which $I$ in my conscience think the best,' and, as he afterwards added, 'denied to none.' '

The writing of George $I$ is very cramped and at times difficalt to decipher. He has two leading ideas: one, not to allow France and Spain to unite, and the other not to let Hanoverian coffers be unduly drawn upon by English adherents. Thus he writes to Marlborough from Hanover on 14 Dec. 1706 : 'I believe it very material to stipulate in the most solemn manner that neither the crown of Spain nor any of its dependencies can ever be possessed by a prince of the royal family of France, whether elder or younger, whether in a direct or collateral line.'

George accepted the guidance of his agents Bothmar and Schütz, and looked to the whigs as friends, yet he would do little to consolidate a party in London by means of the bribery necessary to keep even the protestants from corresponding with the Pretender. Thus Robethon tells $\mathrm{De}$ Grote, his special envoy in London on 14 Jan. 1719, 'Such is the spirit of economy here, especially since the speedy retarn of our troops is looked for, that you must not expect the elector will pat his hand to his pocket even for a master stroke of policy (coup de partie).' The reference is to the proposed measure of sending the Pretender out of France to Rome, and leaving the way clear for Hanoverian diplomacy. Probably the electoral prince thought his chance very problematical. He doubtless knew that Marlborough, and with him half the leading British statesmen, had made professions of attachment to his rival, and feared lest the Pretender turning protestant might even yet incline the English nation towards his interest. This fear finds frequent expression in the Hanover papers; otherwise we should be at a loss to account for such conduct as refúsing De Grote's travelling expenses from Hanover to London when he was employed on a special mission: 'the elector,' Robethon wrote on 3 Feb. 1719, 'refused to give a penny.'

The uncertainty of the Hanoverian succession had for some years been strongly dwelt upon in the letters of a certain Sir Rowland Gwyn, whose compositions are numerous amidat the Hanover papers and seem to be all of one character. According to Gwyn the danger was imminent, and the incoming tory ministers should be looked upon as antagonistic to the protestant interest. Gwyn, we may observe, had been dismissed from the position of page in the princess Anne's household, during the reign of William III, becanse he was then a Roman catholic, but the duchess of Marlborough secured him a pension, and he henceforth remained a subservient creature of the whig party, running after the great Sarah's chair when she appeared in public. ${ }^{2}$ In 1706 Gwyn meddled in Anglo-Hanoverian politics so as to please neither whig nor tory ; he wrote a letter to Lord Stamford concerning the invitation of Princess Sophis to England which, confused though its style was,

' Macpherson's Original Papers.

2 Letters of Sarah, Duchess of Marlborough, p. 307 (1742). 
Oct.

nevertheless brought a prosecution on his head.' Being thas in bad odour at home, he henceforth took up the role of alarmist abrosd, still remaining the hamble servant of the electoral family. He appears to have been really a trusted friend of the electress, and his letters between 1703 and 1710 were carefully preserved at Hanover. The following may serve as specimens of his communications :

- I most humbly beg leave to prostrate my self at $\mathrm{y}^{\mathrm{r}}$ Electorall Highnessea feet wishing $\mathrm{y}^{r}$ Electorall Highness a most happy new year and many of them. And that God Allmighty will pour upon your Electorall Highness a most happy new year and many of them. And that God Allmighty will pour down upon $\mathrm{J}^{\mathrm{r}}$ Electorall Highness \& $\mathrm{y}^{r}$ most serene House, all the Blessings that human nature is capable of. May $\mathrm{y}^{\mathrm{r}}$ life be ever happy, long and glorious, \& may many nations and late posterity, bless, \& praise God for having sent into the world so good a Prince to Protect \& take care of them.

' May yr Family ever continue to seek what is for the glory of God, \& the Common good of mankind. Hamburgh, Dec. 81, 1708.'

With reference to the tory majority in 1710 he writes:

' I believe that they have a house of Commons to their mind, but the question is whether they can govern them, when they are met, and restraine them from unreasonable demands yet the House of Lords will be a checque uppon them.'

The little court of Herrenhansen, thus alarmed, despatched Bothmar to London in the first week of November 1711. His fellow-traveller was no less a personage than the duke of Marlborougb, fresh from perusing most implicatory assurances to the Pretender.' 'Peace,' he had therein declared, 'must certainly happen. The people stand in need of tranquillity on both sides. The current of the Nation now seconds the views of the Minister. But peace and all that has been done, favour the ceuse of the King . . . neither Whigs or Tories can be depended upon, as parties.' The prince who gives them most is their greatest favourite. In a somewhat different frame of mind he had written the following letter to Robethon, 18 Aug. 1710. The letter, a holograph, is in the Hanover collection :

'Poor Mr. Cardonall [the duke's secretary] being sick I must ask your pardon for writing in English but I conld not deffer any longer returning sou my thanks for your obliging letter of the 5th and assuring you at the same time the satisfaction I take in the good choice of the Elector has made of Monsieur de Bothmar, our conjuncture in England it is very extraordinary, that it will requier not only his dilligence, but also his utmost prudence, I pray God everything may end for the best, but our dismall aspect seems rather farourable for France than for ourselves, I am with tiuth your most faithful friend and servant, Marcborodar.'

Bothmar by no means justified Marlborough's good opinion, although the situation wasquite as delicate as he expected. Bothmar proved to be a most injudicious agent, and, together with the other members of the socalled Hanorerian junto, made hasty judgments of men and things, which resulted in the future king George I, when in England, throwing all

'Macpherson, Hist. of Great Britain, rol. ii. p. 887.

I Ibid. pp. 503, 504. Also Stuart Papers, 3 Nov. 1711. 
his influence into the whig scale, thus prematurely alienating those who might otherwise have reconciled many influential people to his rule, but who, as it was, either held aloof, or corresponded with the Pretender.

There is a remarkable series of letters written by Lord Strafford, one of the English plenipotentiaries at Utrecht, to the electress Sophis, which are preserved among the Hanover papers. Lord Strafford's attainder early in the reign of George I has been generally understood to have been due to his connexion with Bolingbroke. But this assertion lacks proof. It is true that in May 1712, Strafford writes to his friend the electress, telling her how one Azzurini, an Italian, wrote a letter accusing him of receiving a letter from the Pretender. Bothmar sent Azzurini's statement to the elector, and gave him money and promise of becoming gentleman of the chamber to the elector, little knowing that Azzurini was himself an accredited agent of the Pretender, as is proved by his correspondence now in the British Museum. Strafford's remonstrances however drove Azzurini out of England and into the Bestile. But of the charge against Lord Strafford not a word of confirmation has been found.

Lord Strafford was a strong tory, and as such, finding Bothmar and Schütz taking a line purely whiggiah, reprobated a one-sided alien interference in British politics. His letters are rambling, but not the less full of good sense. The electress, on the other hand, is both clear and concise in her statements, doubtful as to the future, and adverse to what she thought a premature peace. Thus her opinion was expressed in the following terms when first the negotiations commenced at Utrecht:

$\Pi$ me semble que l'Empereur y'est asses cavallierement traite. Autre fois ce n'etoit pas par le bon plaiser du Roi do France qu'on reconnoissoit l'Empereur dans l'Empire, mais tout change dans le monde. Le dessein de la Reine etoit d'abbaisser le Roi de France, comme sa Majeste engaged tant de Princes a luis faire la guerre, et voila la France plus puissante que jamais.

Towards the close of the negotiations, on $18 \mathrm{Jan} .1718$, Lord Strafford wrote to the electress: "The minister of the four circles of the Empire has been with us, and has given us a memorial for the Queen complaining how ill they should be left without Strasburg. They were answered that their not having that town was to be attributed only to the fault of the Princes of the Empire, who none of them found their contingents but hired their troops to aerve in Flanders, and when a proposition was made for a general cessation, which the allies being united might have obtained that place, they opposed it and for the sake of Prince Engene would follow chimerical projects of new battles and sieges.'

As for the state of puolic opinion in Englend after the peace was concluded, Lord Strafford writes to the electress from the Hague on 24 July 1718 : 'Bless God I am born an Englishman in spite of all our fends and divisions which as long as it does not come to a civil war is only a preservative of our libertys. I believe it is pretty plain now we peace-makers shant be hanged at our return as we were threatened. For daily our conntrymen grow more and more pleased with the peace. And how have we been made the dupes of others to pay their war.' 
Lord Strafford gives us, from time to time, pleasant pictures of the events which he witnessed during his official career; for instance, his account of life at Utrecht during the peace negotiations. The French plenipotentiaries came there after the dauphin and his son's deaths, ' habited in long weepers (pleureuses) while the taste of their apparel was the admiration of all.'

Lord Strafford must be credited with having gauged the strength of Louis XIV better than most of his contemporaries. He writes in April 1718: "The Empire thinks of carrying on the war. If the Emperor be beaten, as there is a likelihood, in what condition would the Empire be? Where could the Emperor retire? The plague is at Vienna. All Hungary is ready to revolt.' The writer further points out that the imperialiste can expect no allies in Italy, where they were detested. The event proved the wisdom of his forecast.

The peculiar value of the Hanover papers lies in the fact that (although England claims a first place in the minds of the electoral correspondents) they deal with European matters generally, at an important moment. Notwithstanding the paramount interest to English readers of such a crisis at home as preceded the peace of Utrecht, it is difficult even for them not to be attracted by notices of such a man as Charles XII of Sweden, who had escaped into Turkey after Pultowa, and was endeavouring to effect by diplomacy the ruin of a rival who had worsted him in the field. Mr. James Jeffreys, the English envoy at Bender, gives us a glimpse of the king in the midst of his misfortunes. Writing in 1711, he says: 'The King of Bweden is in perfect health and the wound he hed received in his foot before the battle of Pnltowa entirely cured; I cant but admire the great firmness and resolution his Mrjesty hes shewd ever since he arrived to this place, having in his greatest misfortane and even when his affairs had the worst prospect, not made the least step unworthy of himself, but has treated these people as if he came to give assistance to them rather than to receive any from them.

' The Turkish army has been approaching this place ever since I came thither. I wish the Muscovites may not come before them, for I am now weary of travelling and have no great mind to go to Moscow.'

Mr. Jeffreys says it was difficult to estimate the real numbers of the Turkish forces. Many janissaries were expected-' they must doubtless be many because they move so slowly, and not having yet passed the streight of Constantinople will not be able to come up with the rest of the army this month.'

We learn that the allies accepted Charles's word, and required no public declaration from him, when an international agreement was being contracted. It is worth noting that the Turks of 1711 called last of all on their Arabian and Egyptian contingents, who were useless through fatigue when they arrived.

At this conjuncture Cherles XII wrote himself to M. Palmquist, his envoy at the Hague, instructing him to address the allies with calm resolution : '

- Being informed by your letters that our allies have at last resolved

' The letter in the Hanover colleotion is a copy, and has been translated into English. 
to fulfil their guarantees, and to procure us a reasonsble peace with Denmark, provided we will assure them not to disturb or any way molest the tranquillity of the Empire: you are hereby ordered to lett them know, that tis not in our power to give them assurances of our not entering Saxony, because it will tend to our greatest prejudice, as having resolved never to recede from anything that the ressons of warr or our own interests require: for Sweden will need all the means that are in her power to humble King August especially since those who are bound by treaties to assist her will make not the least advances in her favour.

'As to a peace with Denmark we have alruady declared that we are not unwilling to agree to one with that crown, and we desire that the allys will make serious representations to Denmark concerning this point as becomes guarantees, for we insist upon that guaranty which the allys are obliged to perform without any condition, may be fulfilled without any delay.'

The Russians were outmanceuvred and surrounded in the following engagement, which is described by $\mathbf{M r}$. Jeffeys at greater length than our space allows. A treaty of peace was made between the sultan and the czar, and one learns, with some amusement, that the Russians promised not even to have an ambassador at Constantinople, and that the czar undertook not to molest the Poles. The king of Sweden was to be allowed to return without hindrance to Sweden. On the other hand, Russian merchants were to trede with Constantinople. The Swedish minister was not present when this treaty was signed, and Charles XII, Mr. Jeffreys tells Robethon, wes sorely indignant.

' He went to the Grand Vizir's tent and reproached him for having excluded him out of the tresty, demanding whether be could answer what he had done to his master [the Sultan].'

The vizier's answer, however, displeased the Swede, who turned his back upon the Turkigh general.

This situation is said to have been brought about by the empress Catherine, Peter's wife. Later in the interview, however, Charles XII condesconded to argue with his late ally's commander-in-chief, telling him ' if he would lend him 20 pieces of Cannon that without the loss of one man he engaged to deliver him the Czar with his whole army prisoners.' The vizier, however, replied that 'The peace was already concluded.'

Very few direct notices of Bolingbroke are to be found in the Hanover papers, but his great activity is nevertheless apparent. What his designs may have really been in the years 1713 and 1714 will probably remain an unsolved problem so lung as the world lasts, but in the Hanover papers we find some help in difficult points. One thing is certain : the mutual accusations of Oxford and Bolingbroke, charging one another with favouring the exiles of Bar-le-Duc, alarmed the good people in Henover, and led the elector, ill-informed of events in Lorraine, and misled by his own agents, to edopt harsh counsels of doubtful atility. Bolingbroke sent a formal assurance of his fidelity to the electress in October 1710, and received this reply from Robethon on the following 17 Dec., a copy of which the latter preserved: 
' His Electoral Highness, who read it, has very expressly commanded me to thank you from him for the protestations which it contains of your zeal for the interest of his family, and to assure you that he is very sensible of this, and has a very great esteem and regard for you, knowing your capacity which renders you so deserving of the choice and confidence of the Queen.' Robethon, however, significantly adds in conclusion that when Baron Bothmar returns to London all correspondence must pass through the medium of his hands.

At Herrenhausen, Bolingbroke was in marked disfavour. There is ample evidence in these papers of the anxiety at this historic palace, but little to explain the cause. True, an account appears of the son of James II surrounded by protestants at Bar-le-Duc, Lord Middleton being the only Roman catholic. This fact is mentioned more then once, but meagre beyond belief is the intelligence in regard to the Pretender which filtered into Robethon's cabinet.

There is a guarded reference made by the electoral secretary to the duke of Hamilton, when in 1712 that nobleman absolutely asked the Pretender's leave before accepting a mission from Queen Anne to Paris, which several authorities believe was concerted in order that the French government might be consulted as to the possibility of a Stuart restoration. ${ }^{1}$ The duke, however, having killed Lord Mohnn in a duel, was himself treacherously stabbed by that nobleman's second, General Macartney, a violent whig. Robethon, in a letter to Baron de Grote, deprecates Macartney appearing in the electoral dominions, because as Lord Bolingbroke had demanded his extradition there might ensue a possible embroilment between England and Brunswick-Lüneburg.

Quite late in the day, and but a short time before she died in 1714, the princess Sophia took measures to strengthen the claim which parliament had given her family to the British throne. She was in favour of sending her grandson to England as duke of Cambridge, and also made searching inquiries as to the question of the Pretender's birth. The warming-pan atory still had its votaries, and the truth must at all hazards be known. One Dr. Hugh Chamberlen, as London physician, employed by the court when at St. James's, was consulted, and wrote an important and curions minute relating to events which, though they had happened twenty-six years before, still remained apparently fresh in his memory. He tells Robethon that on 9 June 1688 he was suddenly called away professionally to Chatham, and on his returning the following day a messenger summoned him in hot haste to St. James's Palace. There, he says, he found 'a child newly born loose and undressed in Lady Powys' lap and as I was told bronght forth an hour before I came. I was not long in the chamber when the late Dr. Hamilton came and then Lord Arran. The Duchess of Monmouth having some time before sent for me, and having in the meantime gone to the Queen's levy, left order I should waite for her graces return. She was pleased to make this return for her waiting, that she had been with her Majesty.' The

\footnotetext{
1 Macpherson, Hist. of Great Britain, vol. ii. p. 677; Swift, Four last Years of Queen Anre's Reign.

'Macsulay, Hist. vol. ii. p. 863. Burnet (Hist. of his own Times) asserts that Dr. Chamberlen was not called in.
} 
evidence that the duchess proceeded to give was of a character to satisfy the medical mind, and its reproduction is unnecessary, as the facts stand recorded in the published acoounts of the inquiry which ensued. Dr. Chsmberlen conoludes in words which must have satisfied the electress, 'I take the birth to be genuine, without artifice or disguise, so that I never since questioned it.' Moreover he urged that being a 'notorious whig,' he would never have been sent for if a supposititions child had been brought to St. James's. The risk of discovery would have been too great. The outcome of this conversation was totally to discredit the warming-pan theory, which no official adherent of the house of Hanover adduced.

Dr. Chamberlen continues, "The King coming through the Park to 8t. Jameg' next morning, he was pleased to tell me that when he sent I Was absent; to which I humbly replied, more warning had been necesaary, but he told me they were surprised, for the Queen expected to go a fortnight longer.' James $I I$ and Dr. Chamberlen then entered into a general conversetion on the subject of the birth of children, which it would be tedions to repest here, anless for the curious admission made by the doctor that 'he believed the ecience of medicine to be in its infancy.'

To quiet apprehensions at Hanover, Lord Oxford sent his brother, Mr. Thomas Harley, on a mission to the electoral court. He was the bearer of a letter from Mr. Secretary Bromley in the following terms: - You are to observe to their Electoral Highnesses that their succession is built upon the most certain and solid foundation that anything of this nature is capable of, for they not only have the laws on their side, which are framed in as olear and strong terms as words can express, but also the inclinations of Her Majesty, and the oaths of her people, and Her Majesty hes always considered this settlement as the only means to preserve our Holy Religion and to secure the peace and tranquillity of her subjects.'

Buch strong assurances might well have contented men informed as to the affairs at the Pretender's court and also acquainted with the British constitution. Schütz, Robethon, and Bothmar, however, refused to be comforted, and a vague distrust continued to distarb the household at Herrenhausen. ${ }^{1}$ Offers of support from men of position and influence were highly valued at Hanover about this time, while those written in English were immediately copied, duplicates remaining in Robethon's cabinet. Thus we find that much satisfaction seems to have been felt when Lord Anglesey" and Sir William Dawes, archbishop of York, acknowledged themselves servants of the elector. The former hed long hesitated, and the adherence of the archbishop doubtless possessed great weight. ${ }^{3}$

It was to Archbishop Dawes that the queen about this time gave an

1 Maopherson has printed (Original Papers, ii. 638) the important letter in the Hanover collection in whioh it is stated that Thomas Harley showed the elector copits of Marlborough's correspondence with the Pretender, which grestly impressed Bothmar.

Moopherson, Hist. of Great Britain, vol. ii. p. 628.

- There is a notice of the archbishop in the Rev. J. H. Overton's Lifo in the English Church, 1660-1714, p. 254. 
express assurance of her attachment to the Hanoverian succession. In a letter to the electress dated at Westminster, 27 April 1714, Mr. John Chamberlayne writes as follows:

'And perhaps Madam I should not have ventured to Trouble your Highness so soon upon this occasion only if the Archbishop of York (than whom there is no Man in England more Devoted to your interest) had not acquainted $m e$ in a private conversation this day, and allow'd me at the same time to inform your Highness that her Majesty sent for him very lately, and permitted him with great Liberty, and with that Candor and Sincerity that is natural to his Grace, to lay before her his thoughts of the People's Fears and Jealousys concerning the Pretender, and the dangers to the succession so much apprehended (sic) by all good Protestants. And after that her Majesty had heard him with great Patience and Attention she was pleased to give him the most solemn Assurance of her sincere and unalterable Affection to your Highness and your most illastrious Family, and Resolutions of cultivating the same both by herself and her Ministers.'

Lord Oxford had unfortunately acted during this time with a duplicity equal to that which he had previously exercised as regards St. Germains. He told Robethon he should not be sorry to see a representative of the Brunswick-Lüneburg family in England, while he secretly entered into negotiations with the whigs, telling them that he feared for the succession; and yet simaltaneously he strove to sustain himself with the terrorstricken queen by essuring her that Bolingbroke's violence had led the elector to demand a writ for the electoral prince as duke of Cambridge. ${ }^{1}$ While he andoubtedly did wish well to the elector, he yet added to the vague and probably unfounded alarms which were set afoot concerning the aims of his colleagues. The writ in question was asked for by Schütz, 12 April 1714.

Lord-chancellor Harcourt after seeing the queen wrote to this effect :

' SIR,-When you came to me yesterday, and told me, that by order of the Princess Sophia you demanded a writ of summons for the Duke of Cambridge, I let you know, that I thought it my duty to acquaint her Majesty therewith.

'I have accordingly laid this matter before the Queen, who was pleased to say, that not having received the last intimation of this demand from you, or in any other manner whatsoever, from the Court of Hanover, she could hardly persuade herself that you acted by direction from thence, that she therefore did not think fit to give me any other answer than this.

'The writ for the Duke of Cambridge was sealed of course when the writ of summons to all other peers were sealed, and lies ready to be delivered to you whenever you call for it.

'I am, Sir, your most humble servant,

'A Mons. Sohutz.'

' Harcourt. C[hancellor].

On 4 May 1714 their electoral highnesses despatched jointly a long

1 Macpherson, Hist. of Groat Britain, vol. if. pp. 641, 648. 
memorial to Queen Anne, claiming that the Pretender should be driven out of Lorraine into Italy at all hazards, because his agents bossted, qu'il se prepare d faire incessammont sa descents dans le Monde de la Grande Bretagne, pendant que elle se trouvé degarnie de troupes et de flotes, ce qui est confirme par divers avis de personnes qui ont ete depuis pert a Bas lo Duc, qui ont eu part d la confiance du Pretendant et qui assurent qu'it se mettra bientot en chemin pour execute son entreprise et qu'il conts sur un puissante secours etranger. The letter, which is too long for quotetion, went on (in appearance at least) almost to demand a right of residence for the electoral prince in England.

The queen replied that any additional security their highnesses desired should be forthroming, that the duke of Lrorraine had been written to concerning removal of the Pretender from his domains; but that it could not be imagined that she (the queen) had it in her power to prescribe where the Pretender should go, or by whom he should be received. Mr. Thomas Harley was also directed to say, that 'Correspondence with the Pretender being High Treason by law, Her Majesty would take oare to have that law duly executed ;' further, that a standing army in time of peace being contrary to statute, it was impossible to strengthen the land forces; but that so far from her fleet being short of its proper strength the queen conld put more ships to ses then any other European sovereign. On the other hand she would share her cares with no prince, and the appearance of a foreigner was calculated to disturb public tranquillity. Granting titles to foreigners had made William III unpopular, and she would avoid so doing.

The death of the electress, 8 June 1714 , seemed to increase the anxiety of her adherents as to the English succession, and Robethon concurred with the almost fanstic Schütz as to the necessity of sending a representative to London. The intrigaes of Bchütz proving intolerable, thet minister was dismissed from Englend, lesving a soreness between Qufen Anne and her kinsman at Hanover. To heal this, if possible, bat at the same time to impress upon Robethon and the court he served that the electoral prince must remain out of England during the queen's life, the earl of Clarendon was sent on a mission which seems to have been Bcarcely rated at its due importance.

Lrord Clarendon's mission was announced by the queen to the court of Hanover at the same time she wrote these letters, 19 June 1714 ; but the scheme was prepared in May, when his instructions were drawn up. He was to see one by one all the electoral family, and 'inform them of our particular friendahip for every branch of that serene house.' Moreover, 'you shall during your stay endeavour as much as you can, to inform yourself, of the designs and intentions of that Court, particularly cis they may concern our interest or have influence on the publick affairs at this juncture.' One of the secretaries of state was to give further orders.

Mr. Secretary Bromley's letter is as follows :

'Whitehall, 22nd June, 1714.

' MY LORD,-The Queen coveting nothing so much as that you may be able to conciliate a firm and entire friendship between her Majesty and the 
house of Hanover, I am commanded to acquaint your Lordship, that when you speak to the Elector upon her Mriesty's good disposition; you are to let him understand she hopes it will meet with suitable returns.

' Your Irordship will endesvour to satisfy the Elector the Queen has no intention, but to secure the Succession to her Crowns as by law established in the house of Henover and is ready to do everything that may contribute to that end consistent with the safe and quiet possession of them during her own time. Her Majesty having been very sincere in the public declarations she has made, and in the assarances she has frequently given in favour of this succession; she expects from the Elector he will speak freely on this subject, and particularly if he thinks he has reason to suspect designs are carrying on to disappoint it, that he will declare what foundation he has for such suspicion. .

' And your Lordship will assure him he may depend that no person shall be continued in her Majesty's service he has reasonable ground to imagine has other views, and if that can be made appear her Majesty will not fail to make examples of such persons.

' Upon your Lordship's arrival at Hanover you will learn what resolntion that Court has taken about the Electoral Prince [the duke of Cambridge] coming hither, the demanding the writ for his sitting in Parliament having given an expectation it wes soon intended. Your Lordship will find such resolation is either taken or suspended, or a resolution taken that he will not come over without her Majesty's consent and invitation.

' If the resolution for his coming is taken or suspended your Lordship will represent to the Elector, the great unessiness his coming hither at this time will give the Queen, how unreasonsble it is, and that it may endenger the succession itself.

' It must make the Queen nnessy, as it will be thought to confirm a jealousy, maliciously and industriously spread of her Majesty's want of sincerity and good inclination to the succession and as it will be understood to gratify those who desire, and there is cause to believe have solicited his coming over in opposition to her Majesty. It is unreasonable because of the division among as, which his presence at this juncture will rather foment and increase than compose and quiet. And it may endanger the succession as it will certainly cool the zeal of many well affected for it, who from their duty and regard for the Queen will be diagusted with everything that shall have the appearance of a contemptuons treatment of her Majesty and who will apprehend such a step to be a declaration for the Faction, and entering into the hests and extravagance of a party for whom they have so strong an aversion that they dread nothing more than their returning again into power.

' But if the resolution is taken that the Duke of Cambridge shall not come without the Queen's consent and invitation, your Lordship will let the Elector know that this deference and respect to her Majesty will lay such an obligation on har as will entitle him to all the good efforts he can expect from it.

' Upon the whole your Lordship will observe to the Elector, that as good use may be made of this accident, of this attempt to bring over the Duke of Cambridge in opposition to her Majesty, since the regards he shall shew to her Majesty on this occasion must necessarily create such a 
friendship and good correspondence between her Majesty and him as must be very serviceable to their matual interests.

- I am with all possible respect

$$
\text { My Lord, }
$$

' Yr Lordship's most humble \& obedient servant

'W. BromLey.

Queen Anne had previoualy written to the princess Bophia, to the elector, and to the electoral prince in the strongest terms. She considered the project of sending the duke of Cambridge to England to be atterly out of reason-plus dangereux a la tranquillite do mes etats, au Droit de la succession dans votre ligne. ${ }^{1}$ All three letters were despatched simultaneously, and were to the same effect.

Lord Clarendon reached the Hague, after experiencing some delay, $17 \mathrm{July}$, and was in Hanover on the 31 st. Shortly after his arrival he received the following letter from Mr. Secretary Bromley, dated 27 July 1714 : 'I am directed to acquaint your Lordship that the Queen has removed my Lord Treasurer which your are to take notice of to the Elector, and at the same time to let him know that this domestick incident shall make no alteration with respect to public affairs. The Treasury will be put into commission.'

The Hanover papers in connexion with Lord Clarendon's mission prove that, whatever their designs, Bolingbroke and his friends acted faithfully towards the house of Brunswick, and only desired to be secure from the confusion and possible bloodshed which the proposed advent of the electoral prince seemed likely to bring about.

Lord Clarendon's conduct of his mission afforded evidence that as envoy on a delicate errand he possessed both judgment and capacity. A delay of several days ensued after he had sent his credentials to the elector before an interview conld be arranged. The king of Prussia was in alose converse with his brother of Brunswick Lüneburg, endeavouring to secure the elector's conourrence in a partition of the Bwedish territory of Charles XII. However, on 8 Aug. Baron Bernstorff explained the delay to Lord Clarendon, and assured him that, directly the king of Prussia had left, coaches should be in readiness to take the English representative to Herrenheusen. This occurred on 7 Ang. when the elector not only received Lord Clarendon with cordiality, but soon put it beyond doubt that he intended to conform to her majesty's desire in the matter of the duke of Cambridge residing in England. He told Lord Clarendon the idea had been popular with the late electress, but that in asking for the writ, Schütz had acted without her cognisance and on his own responsibility. In fact, he threw his agent over altogether, a solution that could scarcely have been satisfactory to the whig party in England, who were so deeply involved in the scheme. The elector spoke thus plainly as to his own innocenee, J'espere que la Reine n'a pas cru que cela y'est fait par mon ordre. Je vous assure cela a este fait a mon inscet.

Lord Clarendon formed the opinion that 'The Prince knew little about the English Constitution, and seemed to think that he had been imposed on.' As for the members of the Hanoverian junto, Lord Claren-

I Letter to the Electoral Prince, 19 May 1714. 
don edds, ' Berensdorf is governed by Robethon, who is as bad as bad can be '-Lord Clarendon's way of saying ' bound over to the whigs.'

Schütz seems to have undergone a sort of benishment from court circles, for he was not allowed to approach Herrenhausen, and the brave words spoken in England by those allied for the purpose of bringing over the duke of Cambridge found no favour at Hanover. Policy may have dictated the total surrender, which the Hanover papers relating to these later negotiations prove to have been made. In fact, Lord Clarendon's mission succeeded completely; nor should it be forgotten that when all difficulties were thus cleared away, Lord Clarendon had not received the letter which Secretary Bromley had found it necessary to despatch 8 July, mentioning the seriousness of the state of Queen Anne's health. M. Bernstorff made no demur to what Lord Clarendon told him on a subsequent occasion: 'It was the more neceseary for the Elector to enter into an entire confidence with the Queen as the surest means to secure his interest against the Pretender.'

Such wa the situstion when, after a premonitory warning sent from St. James's, the news of the queen's death reached Hanover. On 17 Ang. Lord Clarendon, seeking a fresh audience of the elector, communicated to him the fact; to which George I replied that the account tallied with that which M. Robethon had received. Lord Clarendon then asked for instructions, and was desired to stay in Hanover until the king set out for his English dominions. The Hanover papers tell us that no hitch or hesitation ensued, except as regards the king's departure, which did not take place for seven weeks.

When Lord Strafford heard of Queen Anne's death he expressed devotion to George I, writing from the Hague on 20 Aug. 1714, "that he was anxious for the King'e arrival,' and saying, 'that the "Perigrin," the best royal yacht available [in which he actually did embark], was awaiting him on the coast of Holland.'

A letter written to Lord Bolingbroke by Matthew Prior from Paria, which Robethon took with other papers to London, reveals the feelings of a tory diplomatist at this time:

\section{Mr. Prior, Paris, to Lord Bolingbroke, London.}

‘ Paris : August 17, 1714.

- Mr LoRD,-We remain still in the sad uncertitude or rather mortal apprehensions of what has happened, nor express, nor news having arrived here since last I writ to your Lordship.

- This Court and the King particularly seem under very sensible concarn in this melancholy conjuncture. Upon the best enquiry I cannot find that any thing is acting for the Pretender. An express has gone to Lorraine from his Mother to acquaint him with the present case of the Queen of Great Britain as signified by D'Herville's express to this Court.

- At this distance I am from you and the light which I see matters from hence you will easily judge my Lord how much I am astonished at what has passed within these three weeks at London. What may pass there in three weeks more God above only knows.

' It is in such extraordinary conjunctures that one either requires or 
needs ones friends, whilst you continue to act as you have hitherto done for the safety and honour of your conntry I will abandon you and life at the same time. Adien, my Lord, God bless you, send me your instructions, and believe that I will always execute them with zeal and truth, and that I am ever and inviolably, my Lord, yours,

'M. Prior.' 1

Prior had written, Aug. 28, to Lord Clarendon at Hanover, promptly announoing the acknowledgment of George I as king of England both by France and Bpain. Strafford, on the other hand, concludes his recently mentioned letter by blaming the duke of Marlborough for making a triumphent entry into the city so soon after Queen Anne's death: 'Was it not base to trample on his Queen and benefactress' ashes as he did to rejoice in her death and vye in popularity with the King his master ?

' His Majesty will find those who made the peace were not so much is ennemies as some would make him believe.'

Very different is the tone of Addison, who says to Robethon, dating from St. James's on 4 Sept. : 'You will find a whole nation in the highest joy and thoroughly sensible of the great blessings which they promise themselves from his Majesty's accession to the throne.

'The removal of Lord Bolingbroke has put a seasonable check to an interest that was making in many places for members in the next parliament and was very much relished by the people who ascribe to him the decay of trade and public credit."

Addison, writing as a whig and newly ohosen secretary to the lords justices, may be forgiven for speaking of his party as the people. His political opponent and literary contemporary Prior took an equally narrow view.

The last portion of the Hanover papers contains many copied letters as well as some originals. They take us into those times when, during the years 1716 and 1717, a triple alliance between England, France, and Holland aroused the jealousy of the empire to such an extent that Prince Eugene, the imperial commander, wrote three sympathetio letters to the Pretender at Avignon. The date of these commnnications, which are of a formal character, is 1717, when the prince was in Belgrade commanding against the Turks.

Another letter concerning the exiled family is extremely curious and has not been printed. Cardinal Alberoni having revived Spain in 1718, and taken the Pretender under his protection, was forced somewhat prematurely into war with the members of the triple alliance. Hence the English fleet onder Sir George Byng, carrying 1,400 gans, came into advantageous contact with the Spanish ships carrying only 1,284, off Mesaina. The Bpanish fleet was nearly destroyed, a wing alone escaping under the command of an Irish officer, one Admiral George Cammock, who was

1 When Prior went to Paris to reconcile the French to the peace of Utrecht, Lrord Btamiford wrote to Robethon: "The distrust I believe it will be out of the power of Mr. Prior's poetry or eloquence to allay; alas, poore man he is himself at low eb.' Although a wreck as regards health and means, Prior lived on to 1721 , having escaped imperchment in 1714. 
nnder the Pretender's direct orders. ${ }^{1}$ Csmmock escsped to Malta with his squadron. Afterwards Byng received a letter from Cammock, calling on him to take his flest into Messina and, joining with that of Bpain, sail towards England. After threatening him with divers penslties ordained of God and Bt. Parl, on the ground ' that whosoever resisteth the ordinance shall receive to himself Damnation,' he adds, 'a death-bed repentance will avail but little for without Restitution repentance availeth nothing.' $\mathrm{H}_{\theta}$ must therefore restore the Pretender, whose appearance and character he thus describes :

'As England has now at this time only a Cypher of a King and a sham pretending Prince of Wales, now Bir George give me leave to lay before you and that with truth the true character of yours and mine lawful master whom God preserve.

' $\mathrm{H}_{\theta}$ is tall, glender, comely, the upper part of his face very much like Charles II, the lower part very much like the late Queen Mother, sharp, quick, Eye very perceptable, his Judgment extremely good on all subjects that are talked on.

' He speaks as good English as if he had had his Educstion in Eng. land, $h \theta$ is well acquainted with the Laws of his Conntry and perfectly with Clarendon's History and the manners of the people of England, whenever he talks of his Subjects it is with great compassion and affection for his poor deluded people. As to his netaral dispositions he is affable, Courteous, hind, generous, brave, and of a forgiving temper, he has no desire of revenge to his worst of enemies on the contrary, for I have had the honour to hear him say at his table to the Duke of Ormond that he would forgive even Marlborough, Sunderland, Townsend and Stanhope, his greatest enemies if it should please God to restore him.'

Admiral Cammock proceeds to set forth the main object of his letter, and offers bribes all round if Sir George will only embrace the project in question :

The King commands me to tell you that if you will bring into Messina or any port of Bpain the majority of your fleet, so that it may be capable in conjunction with the Bpanish fleet to beat the remainder of the Usurper's fleet, that he will reward you with the same title as General Monk had for the restoring Charles II. And for the better maintaining the honour and dignity of Duke of Albemarle, his Majesty will give you one hundred thousand pounds sterling as his royal bounty, for which security the King of Spain will be guaranty, and furthermore First Lord of the Admiralty, or Admiral Commander and chief of his Majesty's fleet, which of those two you will make choice of.'

Cammook goes on to promise each ceptain of the fleet who complies 10,000l. sterling, making him also knight of a newly created order. As to the subaltern officers, they who gave proof of loyalty were to be preferred according to merit. Able seamen and soldiers, on the other hand, were to be paid all arrears of wages'due to them during the time they served the so-called usurping king, George I.

This remarkable letter conclades, as it commenced, with mingled adulation and threatening. It is dated 14 Oct. 1718 , and was apparently

'Mahon's Bist. of England, rol. i. p. 815. 
withheld antil after the general action between the British and 8panish fleets off Messina, which resulted, ss has been said, so disastrously to Spain. Cammock, escesping with his wing of the fleet, added a postsoript to his letter at Valetta.

There appears to have been a woollen trade between Spein and England, for Byng is told that the poor people will combine with whigs, tories, and those concerned in the wool manufactories against the man who destroyed the Spanish fleet, who, nevertheless, has yet a chance if he will consort with M. Patino, the Jacobite agent, under the cover of whom Cammock's bribe was presented.

Among other doouments relating to this period is a humble address of the governor, council, and assembly of Jamaica, which reached George I on 28 Ang. 1717, congratulating the king on 'the happy effects of his wise and steady resolutions for securing his Kingdom against the danger of invasion from the Pretender's Swedish abettor.' The assumed Jacobite sympathies of Charles XII of Sweden were clearly believed even in the West Indies. The Jamaica governor and council then acknowledge his 'Msjesty's tenderness in sending shipe of war to protect the West Indies from Pirates, when affairs at home and specially in the Bound required their presence.' The document is signed by Peter Beokford, speaker.

Lastly, we may notice a strange story told to Robethon about this time, of a Modenese assassin offering to poison the Pretender, but the motive does not transpire. The writer of the warning letter is one Davenant, whose letters are scattered amongst the Hanover series.

Phact M. Thonntos. 